\title{
Muslim Representation on Children's Cyber Literature in Indonesia Deconstructive Semiotics Study
}

\author{
Sujinah $^{1, a)}$, Encik Savira Isnah ${ }^{2}$ \\ ${ }^{1)}$ Muhammadiyah University of Surabaya, Surabaya, Indonesia 60113, ${ }^{2)}$ Muhammadiyah University of Surabaya, \\ Surabaya 60113, Indonesia \\ a) corresponding author: sujinah@pps.um-surabaya.ac.id
}

\begin{abstract}
The emergence of children's cyber literature with Muslim backgrounds presents diverse Muslim representations. This is interesting as a form of religious literacy, so that it is easier for children to understand. However, the diversity of representations makes children confused about what Muslims are, so is there any hidden meaning behind the representations presented by children's cyber literature. This study will examine the representation of Muslims in two children's cyber literature, Upin \& Ipin and Nussa \& Rara in the episode at Rumah Saja, using Pierce's semiotic method and Derrida's theory of deconstruction. The results show Upin-Ipin (Malaysian product) represents Islam without forcing Islamic symbols to appear on the main character, otherwise Nussa-Rara (Indonesian's product) attaches Islamic symbols to the main characters. So it can be concluded from these representations found that the invention is not capricious does not mean not Muslim, "The other" from the representation of the hijab, shows the awareness of the characters in the story. Finally, 'blind pot', which shows the position of Islam as a commodity in Indonesia. The three of them have an influence on children's cognition as target consumers.
\end{abstract}

Keywords: Children's cyber literature, representation of moslem, deconstruction.

\section{INTRODUCTION}

A 6 year old child, at an integrated Islamic school asked his teacher, Ust, "is Upin Ipin a Muslim"? "Why don't they wear caps like Nussa"? This empirical example reminds us as adults, that children have critical abilities for the works that they enjoy. Upin-Ipin, who appears different from Nussa, even though they are both described as Muslim child figures, it is a big question for theories who believe that children's literature is an explicit work [1] as a form of teaching that shapes children's cognition.

Children's cognition is formed from seeing or hearing something, in the study of Upin-Ipin and NussaRara cyber literature, representations are presented through signs both visually and audio. The signs that displayed are what raise the question above. Instead of presenting Islamic teaching discourse, Upin-Ipin and Nussa-Rara also caused confusion for the children. Derrida [2] with his deconstruction theory states that literary works always have "hidden areas" which result in delays in meaning. So it could be that the representation presented by the child character asks for a deconstructive way of reading in order to find a new meaning (invasion). Locke [3] said that children are blank slates or blank paper, which are easy to fill with colors so that they form a certain color. This means that if the given meaning does not suit him, he will grope for the meaning of something, so that adults have an 
obligation to lead children to choose a meaning that is good for him.

Cognition in children is formed from various forms of factors, one of which is repression in children's literature. Upin-Ipin and Nussa Rara are one of a variety of children's literature in the form of cyber or better known as children's cyber literature. Conde [4] states that cyber literature is a literary work whose creation and how to enjoy it requires cyber media (internet pages such as YouTube, devices, internet networks). While Hunt implies that children's literature is all forms of teaching that contain literary values (text, language, discourse) that are conveyed to children, which can be in the form of text, songs, biographies and visuals. [5] So it can be conclude that children's cyber literature are form of teaching in the form of literature in cyber media. Upin-Ipin and Nussa Rara were chosen based on socialblade.com data which shows that both of them are in the highest rating of viewers on YouTube (Indonesian's viewers) for the category of children [6] so they deserve to be research material. In addition, children's cyber literature has become a commodity for children and parents today, especially when Covid-19 hit the world, children are increasingly friendly with cyber. This research is limited to a discussion with the assumption of Indonesian children as the audience.

Not many previous studies have been found related to representations in children's cyber literature, most of them are still in printed children's literature as a source of data, such as Rainan's research [7] on Muslim representations in children's books written by ruling countries such as America. This research shows that the bombing of the WTC (World Trade Center) in 2001 had a huge influence on the figures shown, wearing turbans, white long shirts (robes), veils and many others. Furthermore, Rebecca's research [8], still about representation in children's literature. In her research, Rebecca found that disability representation needs to be conveyed in the work consumed by children, so that they appreciate the differences and realize that people with disabilities have the same opportunities as those without disabilities. Both studies indicate that children's literature is a means of voicing the silenced minds of adults in the real world, so it is worth studying as a result of the cultural views that are fed to children.

On the other hand, there is research on cyber literature, but not children's cyber literature, Thomas [9] conducts research on the character of cyber literature, he concludes that there are new horizons conveyed through new media, namely the internet, so that it is effective for readers to realize technological advances. This is difference with Rokib research [10] which identifies trends, patterns, and approaches in analyzing digital literature in Indonesia. This paper argues that the study of digital or cyber literature in Indonesia is shackled by a polemic. It states that the quality of cyber literature is still in doubt, because it is considered to only change media, from text to hyper-text. Whereas in cyber theory, Bell [11] explains that the cyber world has its own reality which can affect the real world.

The above research conclude that research on Muslim representation in children's cyber literature needs to be done, in addition to the absence of research related to children's cyber literature as a critical effort, namely deconstructive reading to see the meaning by the 'text, to the emergence of children's cyber literature. which is of interest to children in the 5.0 era, which will have a major influence on children's cognition about Islam in Indonesia, which is a country with a Muslim majority.

\section{METHOD}

Semiotika Pierce works with his triadics, namely signs, objects and interpretants. Pierce [12] mentions a sign as a meaning that depends on other signs. This means that to understand the meaning of a sign, it is necessary to relate to other things in an object and is explained by the meaning horizon we have, or interpretant in terms of Pierce. Signs can appear in various forms, for example writing, speech, pictures, color or motion. They are indeed dead when viewed biologically, but their existence has an effect on a person because of the meaning they produce [13]. So it can be concluded that the interpretant is the most important part in reading semiotics. In this article, the author uses the theory of decosntruction as an interpreter in the semiotic method. So that the meaning produced by the interpretant in the semiotic method is based on the deconstruction reading method, which is to dismantle the structure to find the "silenced area" in the work so as to give rise to new inventions or findings of a meaning [2].

The data in this study are a series of visuals and audio which are presented with screen captures (screen shoots) and reincryption of utterances from the UpinIpin episode series "Perintah Kawalan Pergerakan" and Nussa Rara episode "Di Rumah Saja", this episode was chosen based on the pandemic phenomenon is sweeping the world (2020) when research is being done.

The signs that appear in Upin-Ipin and Nussa-Rara will be categorized according to the literary narrative structure, namely themes, characters, plot, background, choice of words and storytelling style, then they will be 
associated with other signs in the work such as movement, Sound, expression, and color are finally read through the lens of deconstruction and a new meaning is found from the representations through these signs.

\section{RESULT AND DISCUSSION}

Upin-Ipin is a children's cyber literature by the Malaysian country which tells the story of two twin boys with aged 5 years who live with Opah and their sister, because of their parents died. The episode of "Perintah kawalan Pergerakan" tells the story of the Covid-19 pandemic that suddenly came, that their economy is in decline. Finally, they choose to sell online to survive in the pandemic. They are Muslim families who living in
multi-RAS areas such as India (Hinduism) and China (Kongghucu). Nussa-Rara, is a work by Indonesian country which tells the story about Nussa (9 years) and Rara (5 years) who live with their Umma because their father works in a separated area. It is told in the episode of "di Rumah Saja", they complained because they were only at home due to the Covid-19 pandemic, but Umma give advised to be grateful because there are still many who have to be outside and at risk of being exposed to Covid-19. Immediately they were excited to help those who still had activities outside.

Both of that story have Muslim family backgrounds with different representations, the differences can be seen in the following table.

Table 1. Sign and object in Upin-Ipin dan Nussa-Rara

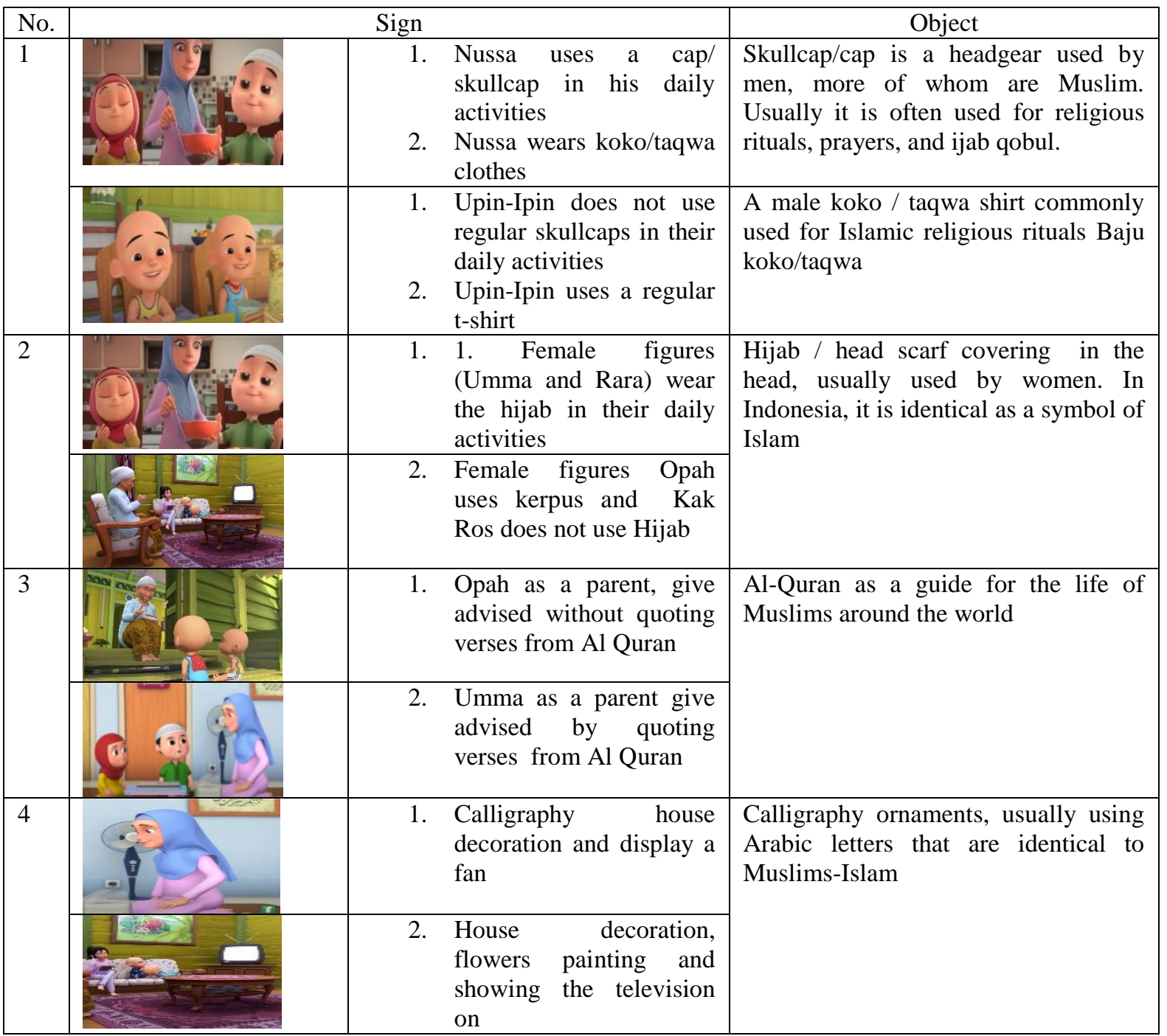




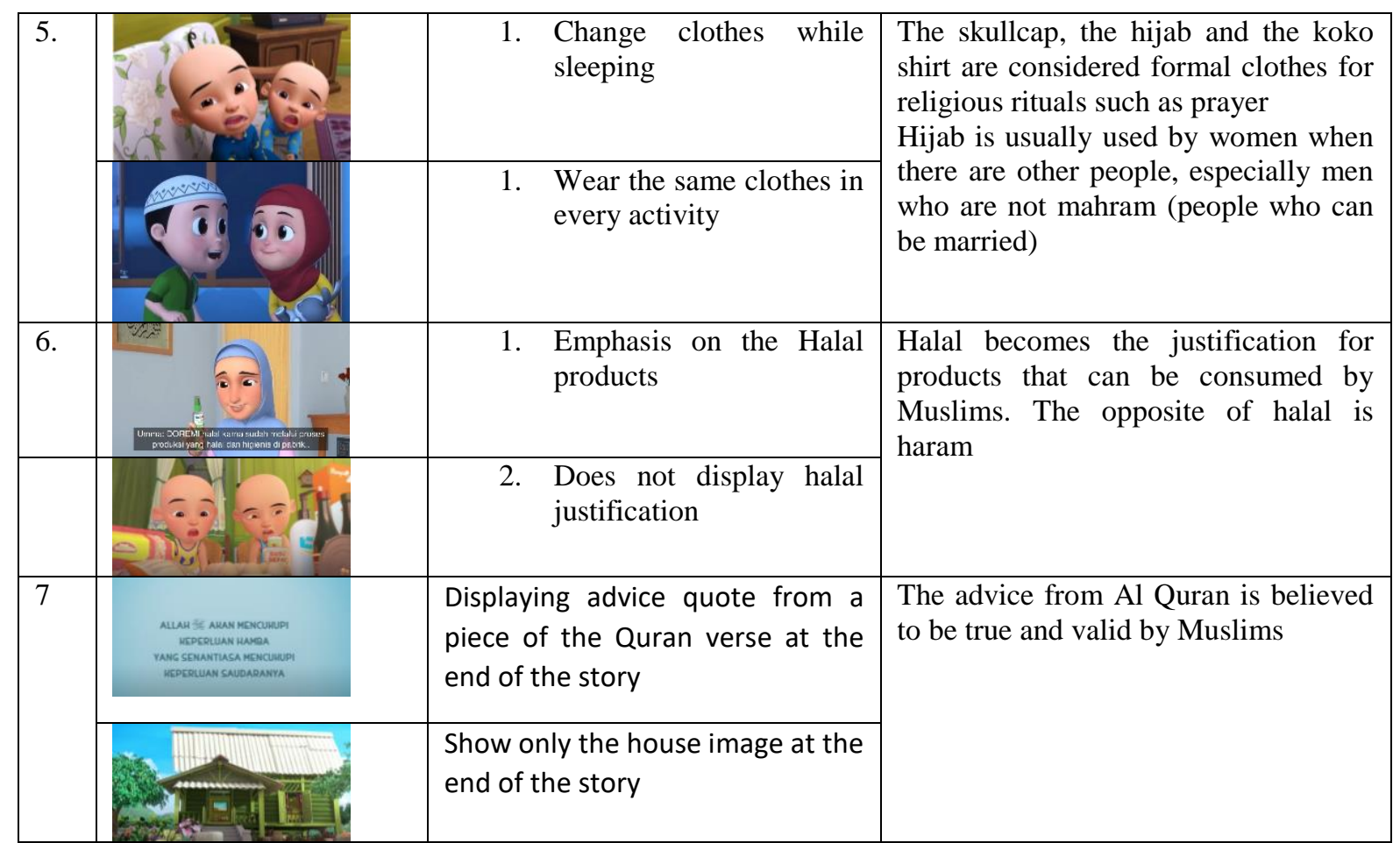

\subsection{Deconstructive Interpretation}

\subsubsection{Inventions \\ from \\ Muslim Representations}

Upin-Ipin and Nussa Rara are present as part of children's literature, which contains teaching for children as a target. The representation of Muslims presented in signs in both works requires an unusual reading method, because "If Upin-Ipin doesn't wear skullcaps in their daily life, that doesn't mean they are non-Muslims, right? Deconstructive reading attempts are made to find the delay in meaning that is being carried out by 'text' to achieve a permanent meaning [14] in terms of cyber literature, not only in writing but also in images and speech. In table 1 it is explained that the main character Upin-Ipin wears a shirt, short pants and does not wear a cap, even though they are said to be Muslim. According to Derrida, the signs conveyed by the text are not always explicit, this means that the Upin-Ipin character shows a delay in the meaning of Muslims by not using the cap but with other forms that need to be dismantled to find it. The Muslims in Upin-Ipin are shown through their actions, such as obeying Opah's orders not to go shopping with Kak Ros, then opah saying "That is the beloved slave of Allah", or "Itulah Budak yang disayang Allah". The opah utterance actually identifies that they are Muslims, even though they do not use [2] a cap and taqwa clothes in their daily activities.

Unlike the Nussa figures who explicitly identify themselves as Muslims by wearing a cap and a koko / taqwa shirt. If you trace back, the term derrida about the historical formation of its meaning, in Indonesia it is not only a symbol of Muslims but also a symbol of masculinity for men as a leader [15]. An article [16] shows that in Indonesia the cap is no longer a symbol of a Muslim but as a national symbol, For example in Ahok, who is not a Muslim, wears a cap when running for district head. So, a red thread can be drawn, with 87.2 percent of Indonesia's population recorded as Muslim, and in its history the peci was not a distinctive symbol belonging to Indonesia but came from Arab traders who stopped in Indonesia, the cap is a symbol that is agreed upon as a peculiarity of men in Indonesia because the majority of Muslims. But behind that, the deconstructive theory reads that, there is an assumption that non-Muslims are not well accepted in Indonesia, therefore in order to be accepted they must be mimicry or resemble Muslims, one of which is by using a cap, so that Indonesian men are identical with a cap regardless of their religion. These traces are stored in the cap as a representation of Muslims.

The Upin-Ipin, who wear shirts, shorts and no hats, in Malaysia did not identify that they were not Muslim. The meaning is obtained from the 'trace' of the text 
which is the result of the author's thoughts, but Derrida firmly says that deconstruction is inside the text and does not work from outside the text [17]. This means that the text that seeks to show children as the audience does not only see one form of representation of Islam, not the author, because what is present is the text, not the author. "The text" shows that in Malaysia the clothes that are used in daily life cannot be used as a measurement point for one's religion or obedience. This goal allows children not to form a cognition that Muslims are only wearing a cap and wearing a koko / taqwa, with the author's awareness that the sign presented has a specific purpose, not just a patch [18]. In contrast to the author of Nussa from Indonesia, who made the symbol of Islam as a legitimacy and identification for Muslim figures. The taqwa cap and clothes used by Nussa make children form cognition. Muslims are people who wear taqwa clothes and wear a cap. It is not wrong, but the identification attached to the child with the portrayal of Nussa as a Muslim "may" lead to the child's perception of judging Muslims, namely "who is not like Nussa is not Muslim". This picture is similar to the fanatsime of religion (Islam) that often occurs in Indonesia [19], which is not good to maintain.

\subsubsection{The Presence of "The Others" that the Character Recognizes}

Likewise with the Muslim representation presented in the form of a hijab. Upin-Ipin's realistic storytelling style shows everyday life by imitating the real world. The characters in Upin-Ipin are not aware of being a work that is enjoyed or seen by humans outside of their storytelling. In deconstruction, 'the other' originates within the work itself. This means that 'the other' is not presented intentionally, as can be read or seen, but as a sign that constructs the identity of the text itself [17]. In the context of this research, 'the other' is the awareness of a character who tries not to be shown explicitly by the text that he is a character in a story, which means that they are not real in the human world and only lives in the world of stories. This means that Kak Ros is a female character who does not close her aurat, she don't wear hijab when doing activities at home, as well as Upin Ipin who doesn't wear koko and cap like Nussa at home, they only use it when going to mosques or other religious rituals, because they are characters in a story who only have awareness in their own world, namely the world of storytelling without realizing the existence of the 'the other', namely the audience who sees them. So it is natural that Sis Ros is not wearing a hijab because there are no men other than her muhrim who are in the scene.

Instead, Umma and Rara, in every situation always wear a hijab, because they are aware that there is "another" who is watching their presence so it is obligatory for women to cover their genitals so that they are not seen by their non-muhrim. This form of awareness in cyber theory is described as hyperealita [20], namely the reality in the cyber world that cannot be defined by the real world (the earth and its creatures).

This form of representation produces a different awareness in each work. The audience (the first person) is invited to be part of the world of Nussa, namely the cyber world, with third person awareness (meaning that the first person is needed to interpret its existence), but not with the biological body, only with the hijab attribute used by Rara and her umma in all situation in their home. This representation in the hijab symbol also forms children's cognition, that Muslim women must wear the hijab when seen by others.

\subsubsection{Blind Spot Through Muslim Representation}

The presence of calligraphy, quotations from AlQuran verses and halal justification to the Nussa Rara show the supremacy of Islamic discourse in Indonesia. So it is not surprising that these representations have become a commodity in Indonesia. For example, there are many advertisements for beauty care products that emphasize the halalness of the product compared to the function of the product itself, then it is easy for Indonesians to believe in figures who carry verses from the Quran, remember the case of Ahok and Rizieq. Based on this, the representation presented by Nussa shows that, that is Muslim, if you can convey the verses of the Quran you can be legitimized as a Muslim.

Delayed meaning of Muslims representing carried out by the work of Upin- Ipin, namely that they have a blind spot or 'hidden area' which is repressed in the text. This work does not explicitly display the signs of Islamic identity as the Nussa series works, but instead appear in utterances and conversations that require 'another logic' to play a role in it. For example:

Upin, "Nak ikut Kak Ros bantu belanja, Opah?" (Upin, "Son, come with Kak Ros to help with shopping, Opah?")

Opah, "Di rumah je kau rang de jadi budak baik yang di sayang Allah" (Opah, "At home you can become a good slave who is loved by Allah") 
The saying "loved by Allah" becomes a hidden area that can be read as a representation of Muslims. Allah is the name of God used in Islam, Allah occupies the highest position in Islam, explained by Jasmi [21] that the best of Muslims is the one who is loved by Allah. It can be concluded, if loved by Allah, it means that you have become a good Muslim. This is what is meant by hidden territory, without having to bring up a verse in Opah's advice, the scene and the utterance have become a form of Muslim representation.

The forms of representation presented in the signs in table one are not intended to make a justification [18], but rather to show how the work produces representations, in this study Muslim representations. The reading of deconstructive semiotics on Upin-Ipin and Nussa Rara resulted in an invention, namely new meanings resulting from ignoring general things that are considered true [14]. Muslims are not only humans who wear a cap, hijab and koko shirt but also when their actions contain Islamic teachings, such as obeying their parents. Second, cyber literature for children has its own awareness, so that it presents 'the other', which indirectly affects the way the audience thinks, for example Umma and Rara who still wear a hijab because they are aware that the audience is seeing them. Finally, the representation of Muslims in the two works shows the position of Islam-Muslims in a country. In Indonesia, Islam is seen as a commodity, read deconstructively by the text itself, in Nussa-Rara and Upin-Ipin. This shows that Nussa-Rara teaches children about Islam which is so rigid and sharp, the assumption of the author, that the aim of children is to form a cognition about the "power" of Islam, especially in Indonesia.

In Indonesia, Islam is a very sensitive sexist discourse. Interestingly, Upin-Ipin's presence as a part of children's cyber literature can be well received in Indonesia even though the Islamic identity that is displayed is very different from the cyber literature created by Indonesian. Nussa, as evidenced by the quantity of viewers from Indonesia who dominate on his Youtube account. Instead, the presence of Nussa as a children's cyber literature by Indonesia can be a form of representation of Islam Indonesia in the world, because children's cyber literature can be accessed by anyone in the world who has an internet network.

\section{CONCLUSION}

Upin-Ipin and Nussa-Rara, as children's cyber literature, raised representations of Muslims in signs that were displayed through pictures and speech. Upin-Ipin more emphasized on the word in utterance as a representation of Islam, on the other hand, Nussa-Rara exploited Islamic representation through symbols such as a cap, koko shirt, hijab, calligraphy, and quotations from the Quran. Behind the representations presented present the invention, 'the others, and the blind spot when read by means of deconstruction. The invention gave rise to a new meaning of the status quo about Muslim representation, namely that no cap does not mean that it is not Muslim. "Another" representation of the hijab, shows the awareness of the characters in the story. Lastly, Blind Spot, shows that there are areas that should be carefully read as representations of Muslims. All three have an influence on children's cognition as target consumers.

\section{REFERENCES}

[1] Nodelman P, Nodelman P. literary theory and children 's literature Children ' $\mathrm{s}$ Literature as Women's Writing. 2018;13(1):31-4.

[2] Derrida J. Psyche: Invention of The Other. In: Atridge D, editor. Jacques Derride: Acts o Literature. New York: Routledge; 1992.

[3] Locke J. Second Treatise of Government. first prin. Los Angeles: Enchanced Media; 2016.

[4] Conde XF\& AL. Cyber-literature, Micro-stories and Their Exploitation. ARS AETERNA. 2012;2(1):16.

[5] Hunt P. A book review by Danny Yee (C) 2016 http://dannyreviews.com/. 2016;

[6] social blade. best 250 for more kids indonesia [Internet]. 2020. Available from: www.socialblade.com

[7] Raina SA. Critical content analysis of postcolonial texts: Representations of Muslims within children's and adolescent literature. Diss Abstr Int Sect A Humanit Soc Sci [Internet]. 2010;70(11-A):4215. Available from: http://ezproxy.library.uvic.ca/login?url=http://se arch.ebscohost.com/login.aspx?direct=true $\& \mathrm{db}=$ psyh\&AN=2010-99091-139\&site=ehostlive $\&$ scope $=$ site

[8] Trew RJ. Representation in Children's Literature: An Analysis of Disability in Picturebooks [Internet]. Western Oregon; 2020. Available

from: https://digitalcommons.wou.edu/honors_theses/2 33/

[9] Thomas E. Cyber Stories In Malayalam Literature. J Chem Inf Model. 2019;53(9):1689_ 99.

[10] Rokib M. The Polemics of Digital Literature in Indonesia. 2019;380(SoSHEC):287-92.

[11] Bell D. CybercultureTheorists: Manuel Castells and Donna Haraway. oxon: Routledge; 2007. 2 
p.

[12] Pierce CS. Pierce on Signs: Writing on Semiotic. Hooper J, editor. Chapel HIll \& Hill: University of North Carolina Press; 1991. 10 p.

[13] Liszka JJ. A General Introduction to The semiotic of Cahrles sanders Pierce. Bloomington \& Indianapolis: Indiana University Press; 1996.

[14] Derrida J. Dissemination. terj. Barb. Chicago: The University of Chicago; 1981.

[15] Kartika BA. Mengapa Selalu Harus Perempuan: Suatu Konstruksi Urban Pemenjaraan Seksual Hingga Hegemoni Maskulinitas dalam Film Soekarno. J Urban Soc Arts. 2015;2(1):35-54.

[16] Hamid, Ali Imron UR. Relasi Elite Politik Dengan Media (Studi Representasi Proses Pencalonan Ahok Sebagai Calon Gubernur Di
Pilkada Dki Jakarta 2017 Di Tempo.Co). J Akrab Juara. 2020;5(2):13-26.

[17] Bradley A. Derrida's Of Grammatology: An Edinburgh Philosophical Guide. Edinburgh: EdinBurgh of University; 2008.

[18] Culler J. The Pursuit o Signs. New York: Routledge; 2001.

[19] Hanafi I. Agama Dalam Bayang-Bayang Fanatisme; Sebuah upaya Mengelola Konflik Agama. Toler Media Ilm Komun Umat Beragama. 2018;10(1):48.

[20] Viires P. Literature in Cyberspace. 2017; (August 2005).

[21] Jasmi KA. Bani Israil dan Perjanjian dengan Allah SWT: Surah Al-Baqarah ( 2: 83-86). 2019;(January):83-6. 